\title{
ANALISIS JENIS, BENTUK, DAN FUNGSI TINDAK TUTUR BERITA UTAMA PADA KORAN BALI POST
}

\author{
Luh Yuli Purnamentari ${ }^{1}$, I Nengah Suandi ${ }^{2}$, Ni Made Rai Wisudariani ${ }^{3}$ \\ Jurusan Pendidikan Bahasa dan Sastra Indonesia \\ Fakultas Bahasa dan Seni \\ Universitas Pendidikan Ganesha \\ Singaraja, Indonesia \\ e-mail: yulipurnamentari@gmail.com,nengah suandi@yahoo.co.id. \\ rai.wisudariani85@gmail.com
}

\begin{abstract}
ABSTRAK
Penelitian deskriptif ini bertujuan untuk mengetahui (1) jenis tindak tutur yang terdapat dalam berita utama pada koran Bali Post, (2) bentuk tindak tutur yang terdapat dalam berita utama pada koran Bali Post, dan (3) fungsi tindak tutur yang terdapat dalam berita utama pada koran Bali Post. Subjek penelitian ini adalah tuturan yang terdapat dalam berita utama pada koran Bali Post. Data dalam penelitian ini dikumpulkan melalui metode dokumentasi dengan instrumen kartu data. Berdasarkan analisis yang dilakukan, hasil penelitian ini menunjukkan (1) berita utama pada koran Bali Post mengandung tindak tutur lokusi dan ilokusi, (2) bentuk yang dominan digunakan dalam berita utama adalah bentuk deklaratif sebanyak 27 bentuk, (3) berita utama mengandung fungsi tindak tutur, fungsi asertif sebanyak 27 , fungsi direktif sebanyak 4 , fungsi ekspresif sebanyak 1 , fungsi deklarasi sebanyak 1 dan tidak ada fungsi komisif. Di antara fungsi tersebut terdapat fungsi yang lebih dominan digunakan pada berita utama yaitu fungsi asertif. Fungsi asertif dapat dibagi menjadi tiga, yaitu asertif menegaskan, asertif mengumumkan, dan asertif menduga. Fungsi asertif lebih dominan digunakan karena fungsi tersebut berguna sebagai ungkapan untuk tuturan menegaskan, menduga, dan mengumumkan sesuatu kepada mitra tutur.
\end{abstract}

Kata kunci: bentuk tindak tutur, fungsi tindak tutur, jenis tindak

\begin{abstract}
This descriptive research aimed at understanding (1) kind of speech act on main news of Bali Post newspaper, (2) form of speech act on main news of Bali Post newspaper, and (3) the function of speech act on the main news of Bali Post newspaper. The subject of the study were phrase on the main news of Bali Post newspaper. The data were obtained through the documentation method by using data card instruments. Based on the analysis that had been done, the result of this study showed (1) main news on Bali Post newspaper contained speech act of locution and ilocution, (2) the dominant form used on main news was 27 declarative form, (3) Main news that contained the function of speech act, the assertive function were 27 , directive were 4 , expressive function was 1 , declaration function was 1 and there were no commissive function. Among those functions, there were more dominant function that was used on the main news that was assertive function. Assertive function was divided into three such as, explaining assertive, announcing assertive, and presuming assertive. Assertive function dominantly used because that function was useful as an expression to explaining speech, presuming speech and announcing speech to the opponent of speech.
\end{abstract}


Key words : of speech act, the form of speech act, speech act function

\section{PENDAHULUAN}

Tidak bisa dipungkiri manusia sebagai makhluk sosial memiliki hubungan dan interaksi yang erat dengan sesamanya. Interaksi manusia ditujukan untuk dapat berkomunikasi dengan orang lain dengan menggunakan berbagai cara baik secara lisan maupun tulisan karena pada hakikatnya, komunikasi merupakan aktivitas yang tidak dapat dipisahkan dari kegiatan sehari-hari. Kehidupan sosial saat ini tidak dapat terlepas dari teknologi informasi. Kebutuhan akan informasi menjadi kebutuhan mendasar dalam memahami berbagai peristiwa sosial yang terjadi. Informasi-informasi ini dapat diperoleh melalui bergai media. Media massa yang masih dipercaya masyarakat untuk mendapat informasi sosial yang terjadi adalah media cetak berupa surat kabar atau koran.

Surat kabar atau yang lebih dikenal dengan sebutan koran, merupakan salah satu media informasi yang ada di masyarakat. Surat kabar sudah dianggap sebagai media informasi yang efisien, di samping televisi dan radio (Ajick, 2011:1). Koran menjadi salah satu produk jurnalistik yang telah merakyat karena mudah didapatkan dan harganya terjangkau. Bukan hanya kalangan pejabat dan pengusaha yang membaca koran, tetapi semua kalangan masyarakat mulai dari tukang becak, pedagang, supir angkot, tukang parkir, guru, mahasiswa, dan lain sebagainya. Dengan membaca surat kabar, pembaca dapat terus mengikuti perkembangan-perkembangan aktual baik dalam negeri maupun luar negeri.

Di dalam surat kabar tidak hanya memuat berita-berita yang menginformasikan kepada pembaca secara objektif mengenai suatu hal yang terjadi di dalam komunitas, negara, dan dunia, tetapi juga mengomentari peristiwa yang terjadi yakni berupa opini, menyediakan informasi bagi pembaca yang membutuhkan barang dan jasa melalui pemasangan iklan, dan memberikan hiburan kepada pembaca untuk mengimbangi berita-berita berat dan artikel-artikel berbobot dengan sajian cerita komik, kartun, teka-teki silang, dan humor. Bila mengetahui fungsi surat kabar seperti itu, sudah tentu begitu banyak manfaat yang didapat dari membaca surat kabar. Kegiatan membaca surat kabar termasuk kegiatan yang sederhana dan mengeluarkan modal sedikit. Ajick (2011:2) mengatakan hanya dengan melihat dan memahami isi yang tertulis di dalam surat kabar dapat menjadikan kegiatan sederhana yang membutuhkan modal sedikit, tapi menuai begitu banyak keuntungan.

Salah satu surat kabar atau koran yang terkenal dan beredar di Provinsi Bali adalah koran Bali Post yang juga merupakan koran tertua di Provinsi Bali. Cikal bakal koran Bali Post adalah "Harian Suara Indonesia" yang diterbitkan Nadha pada tanggal 16 Agustus 1948, saat revolusi bersenjata di Indonesia masih terjadi. Ketika situasi politik berubah, Harian Suara Indonesia harus berganti nama menjadi "Harian Suluh Indonesia" pada tahun 1966 dan berganti lagi menjadi "Harian Suluh Marhaen" pada tanggal 1 Juni 1966 sampai dengan pada tanggal 1 Mei 1971. Nadha dan kawan-kawannya lalu mendirikan "PT Bali Press" dan menerbitkan "Harian Umum Pagi Bali Post" dengan Surat Izin Terbit No. 0359/PER/SK/DIR PP/SIT/1971 mulai sejak pada tanggal 1 September 1971. Koran yang terbit sejak pada tahun 1972 ini juga menjadi anggota Serikat Penerbit Surat Kabar (SPSK).

Bali Post merupakan koran yang memuat informasi yang bersifat internasional, nasional, dan regional (daerah), serta dibaca oleh sebagian besar masyarakat Bali, baik kalangan 
bawah, menengah, maupun kalangan atas. Koran Bali Post terbit setiap hari, kecuali hari-hari besar keagamaan. Koran Bali Post terdiri atas beberapa rubrik, salah satunya berita utama. Sebagai salah satu koran yang menjadi favorit masyarakat di Bali, berita utama yang ada di halaman depan koran harus dirancang sedemikian rupa, sehingga berita yang disajikan mudah dipahami oleh pembaca dari berbagai latar belakang sosial. Berita utama merupakan berita yang berjenis straight news atau berita langsung. Biasanya dalam berita utama ini disajikan berita yang terbaru atau aktual, apa adanya, serta ditulis secara singkat dan lugas.

Berita utama yang bisanya menjadi daya tarik awal para pembaca koran atau surat kabar dapat dibagi menjadi beberapa bagian yaitu: (1) Headline atau kepala berita disebut pula dengan judul. Judul berita ini biasanya juga memiliki anak judul. Headline ini bertujuan untuk memberi tahu pembaca tentang inti atau pokok berita, dan menekankan suatu pesan tertentu yang ingin disampaikan dalam berita; (2) Lead merupakan paragraf inti yang merupakan rangkuman suatu berita. la juga disebut sebagai teras berita yang merupakan paragraf pertama dalam berita. Tanpa membaca keseluruhan isi berita, secara garis besar pembaca akan mengerti isi berita tersebut hanya dengan membaca lead-nya saja. Meski demikian, pembaca tidak akan menemukan penjelasan detail jika hanya membaca lead dan tidak membaca keseluruhan isi berita; (3) Body merupakan isi berita yang melaporkan suatu peristiwa tertentu dengan gaya bahasa yang padat, jelas, terstruktur, kronologis, dan mengandung unsur $5 \mathrm{~W}+1 \mathrm{H}$ (Who, What, When, Where, Why dan How).

Tujuan pembutan berita utama adalah untuk memberikan informasi kepada pembaca mengenai hal-hal yang baru saja terjadi yang sedang hangat diperbincangkan mulai dari bidang politik, sosial, pendidikan, pemeritahan serta ekonomi sehingga berita utama selalu mendapat perhatian dari para pembaca berita. Berita utama dalam sebuah surat kabar atau koran mengandung tindak tutur. Tindak tutur tidak hanya bersifat lisan, namun terdapat juga tindak tutur yang dituangkan dalam bentuk tulisan atau teks. Karena adanya suatu tuturan dalam berita utama koran Bali Post, maka berita utama dapat dianalisis dari tindak tuturnya. Berita tama adalah sebuah teks, jika diteliti lebih lanjut menggunakan kajian tindak tutur, berita utama dapat dianalisis berdasarkan jenis, bentuk, dan fungsinya yang dapat mengungkap makna sebenarnya.

$$
\text { Kenyataan di lapangan }
$$

menunjukkan bahwa masih banyak pembaca yang gagal paham dengan isi berita utama. Berdasarkan hal tersebut, berita utama ini dianalisis berdasarkan aspek pragmatik. Pemilihan pragmatik sebagai bahan kajian penelitian ini karena dasar pragmatik mampu memahami dan menafsirkan maksud tulisan dalam berita utama. Pada penelitian ini dikhususkan pada tindak tutur.

$$
\text { Tindak tutur adalah }
$$

berlangsungnya interaksi manusia yang melibatkan dua unsur pokok yaitu penutur dan mitra tutur. Penutur adalah seseorang yang melakukan tindak verbal, sedangkan mitra tutur adalah seseorang yang menjadi lawan dari penutur. Komunikasi dan kegiatan berbahasa lainnya yang melibatkan penutur dan mitra tutur tersebut menghasilkan aspek yang disebut dengan tuturan. Tuturan yang terjadi dalam sebuah interaksi berbahasa memiliki bermacam-macam maksud yang ingin disampaikan. Berkenaan dengan bermacam-macam maksud tersebut, Leech (1993:19-20) menyatakan bahwa sebuah tindak tutur mencakup (1) penutur dan mitra 
tutur (2) konteks tuturan (3) tujuan tuturan (4) tindak tutur sebagai bentuk tindak atau aktivitas (5) tuturan sebagai produk tindak verbal.

Tindak tutur merupakan salah satu objek kajian pragmatik. Pragmatik mempelajari bagaimana bahasa digunakan dalam komunikasi, dan menyediliki makna sebagai konteks, bukan sesuatu yang abstrak dalam komunikasi (Wijana,1996:2). Berdasarkan uraian tersebut, makna yang menjadi kajian pragmatik adalah makna yang terikat konteks. Penutur dan lawan tutur dapat memanfaatkan konteks untuk memudahkan memahami makna tuturan.

Tindak tutur sendiri merupakan suatu tindakan yang tampak pada makna atau maksud tuturan. Dalam pragmatik, tindak tutur dapat digolongkan ke dalam beberapa pengertian yang berdasarkan jenis, bentuk dan fungsinya. Berdasarkan jenisnya, tindak tutur menurut Austin (dalam Maharani 2007) dibagi menjadi tiga jenis tindak tutur: (1) tindak 'lokusi' yang mengaitkan suatu topik dengan satu keterangan dalam suatu ungkapan, serupa dengan hubungan 'pokok' dengan 'predikat' atau 'topik' dan penjelasan dalam semantik, (2) tindak 'ilokusi' yaitu pengucapan suatu pernyataan, tawaran, janji dan sebagainya, dan (3) tindak 'perlokusi' yaitu hasil atau efek yang ditimbulkan oleh pendengar tuturan stelah mendengar kalimat yang didengar.

Dilihat dari segi bentuk dan fungsinya menurut Wijana (dalam Chaer dan Agustina, 2010:18) tindak tutur dapat dibagi menjadi tiga, yaitu tuturan bermodus deklaratif, interogatif, dan imperatif. Berdasarkan fungsinya tindak tutur dapat dibagi menjadi lima, yaitu (1) asertif atau representatif yang berfungsi untuk menguatkan, menduga, menegaskan dan mengumumkan; (2) komisif memiliki fungsi untuk melakukan sesuatu misalnya besumpah atau berjanji; (3) direktif memiliki fungsi untuk mendorong pendengar untuk melakukan sesuatu, misalnya menyuruh, meminta, menasehati; (4) ekspresif adalah tindak tutur yang menyangkut perasaan dan sikap, seperti meminta maaf, berterima kasih dan lain sebaginya; (5) deklarasi, yang berfungsi untuk memutuskan sesuatu seperti menghukum, memecat, memberi nama, dan sebaginya.

Penelitian mengenai tindak tutur telah banyak dilakukan pada media iklan televisi,komik strip, sinetron ataupun teks pada baju kaos. Salah satu penelitian tindak tutur dengan judul "Jenis, Bentuk, dan Fungsi Tindak Tutur Meme Comic pada Facebook"dilakukan oleh I Gusti Ayu Ratih Sintya Dewi pada tahun 2016. Ratih melakukan analisis terhadap meme yang terdapat dalam sosial media. Penelitian Ratih menggunakan meme comic yang didapat dari media sosial "facebook", yang diunggah dari tanggal 1 September sampai 30 September 2016. Penelitian ini dikaji menggunakan pendekatan deskriptif kuantitatif dan kualitatif. Penelitian kuantitatif merupakan penelitian yang akan menentukan hasil berupa jumlah dalam bentuk angka berapa banyak meme comic yang jenis lokusi, ilokusi, dan perlokusi yang ditemukan, serta berapa banyak meme comic yang tergolong ke dalam bentuk deklarasi, interogatif, dan imperatif, dan berapa banyak meme comic yang menggunakan fungsi asertif, komisif, direktif, ekspresif dan deklarasi. Sedangkan pendekatan kualitatif digunakan untuk mendeskripsikan analisis tentang jenis, bentuk, dan fungsi yang terdapat pada meme comic. Ratih menggunakan kajian tindak tutur dalam pragmatik yang juga sama dengan kajian yang peneliti gunakan. Peneliti mengambil data pada "koran Bali Post", sedangkan Ratih mengambil data pada "facebook", dan cara serta 
permasalahan yang peneliti angkat sama.

Penelitian lain mengenai tindak tutur juga dilakukan oleh Nova Avidia Ananda dengan judul penelitian "Bentuk dan Fungsi Tindak Tutur Slogan Varian Iklan Pond's di Televisi" pada tahun 2015. Nova melakukan penelitian tentang slogan-slogan varian iklan pond's yang terdapat pada berbagai siaran televisi dengan menggunakan kartu data untuk mengumpulkan data agar penelitiannya berjalan secara sistematis. Pada penelitian ini, Nova menggunakan metode simak, metode padan dan kartu data untuk memperoleh data. Dari penelitian yang dilakukan oleh Ananda terdapat persamaan dan perbedaan dengan penelitian yang peneliti lakukan. Persamaannya yaitu sama-sama membahasa tentang bentuk dan fungsi tindak tutur, namun perbedaannya dengan penelitian yang peneliti lakukan yaitu peneliti meneliti tentang berita utama dan menambahkan satu permasalahan lagi yakni tentang jenis tindak tutur yang terdapat pada berita utama dan menggunakan berita utama pada koran Bali Post sebagai objek penelitian, sedangkan Ananda meneliti tentang varian iklan pond's di televisi. Selain itu, peneliti juga menggunakan kartu data yang berbeda untuk mengumpulkan data. Berdasarkan

dari permasalahan tersebut, peneliti merasa penting untuk melakukan penelitian mengenai tindak tutur yang terdapat pada berita utama koran. Data berita utama yang digunakan sebagai objek penelitian diambil dari koran Bali Post tanggal $1 \mathrm{~s} / \mathrm{d} 30$ Desember 2016. Koran Bali Post dipilih sebagai objek penelitian ini karena koran Bali Post merupakan koran tertua di Bali dan paling banyak diminati, khususnya di Provinsi Bali. Dari penelitian ini diharapkan mampu menunjukkan jenis, bentuk, dan fungsi tindak tutur yang terdapat di dalam berita utama pada koran Bali Post.

\section{METODE PENELITIAN}

Dalam metode penelitian ini, akan dibahas tentang (1) rancangan penelitian; (2) subjek dan objek penelitian; (3) metode pengumpulan data; (4) instrumen penelitian; (5) metode analisis data.

Rancangan penelitian yang digunakan dalam penelitian ini adalah rancangan penelitian deskriptif kualitatif. Deskriptif kualitatif bersifat analitis. Data yang diperoleh seperti hasil pengamatan, wawancara, pemotretan, analisis dokumen, catatan lapangan, disusun peneliti di lokasi penelitian, tidak dituangkan dalam bentuk angka-angka. Peneliti segera melakukan analisis data dengan memperkaya informasi, mencari hubungan, membandingkan, menemukan pola atas dasar data aslinya. Hasil analisis data ini berupa pemaparan mengenai situasi yang diteliti kemudian disajikan dalam bentuk uraian naratif (Setyosari, 2010:181). Data yang dideskripsikan dalam penelitian ini adalah data-data berupa bentuk, fungsi, dan jenis tindak tutur yang ada dalam berita utama . Data tersebut diambil dari beberapa contoh berita utama yang ada pada koran Bali Post.

Subjek penelitian ini adalah tuturan yang terdapat pada berita utama pada koran Bali Post. Objek penelitian ini adalah tindak tutur berita utama pada koran Bali Post. Suatu penelitian harus dibatasi agar penelitian terarah dan tujuan penelitian tercapai. Pada penelitian ini peneliti akan membatasi masalah hanya pada jenis, bentuk, dan fungsi tindak tutur yang terdapat pada berita utama pada koran Bali Post dan diambil dari tanggal 1 Desember sampai 30 Desember 2016.

Metode yang digunakan dalam tahap pengumpulan data yaitu dengan 
menggunakan metode dokumentasi. Tahap pengumpulan data dengan menggunakan metode dokumentasi yang peneliti lakukan dapat dibagi menjadi empat bagian, yaitu 1) Mengumpulkan data berita utama pada koran Bali Post dari tanggal 1-30 Desember 2016; 2) Peneliti membaca teks tuturan yang terdapat pada berita utama secara berulang-ulang agar peneliti tidak melakukan kesalahan; 3) Mengelompokkan data tersebut menggunakan kartu data yang telah peneliti rancang; 4) Pada tahapan terakhir, peneliti kemudian mendeskripsikan data berita utama yang telah dikelompokkan pada tahap sebelumnya berdasarkan jenis, bentuk, dan fungsinya, lalu mendeskripsikan hasil serta pembahasannya.

Instrumen penelitian dalam penelitian ini menggunakan kartu data. Kartu data tersebut digunakan dalam pengumpulan data yang akan digunakan dalam pengumpulan data agar kegiatan penelitian berjalan secara sistematis.

Pada penelitian ini metode analisis data yang peneliti gunakan adalah metode analisis data deskriptif kualitatif. Pegelompokan dan pengabstraksian dilakukan terus menerus selama pengumpulan data tanpa harus menunggu berakhirnya seluruh proses pengumpulan data. Adapun langkah-langkah yang dilakukan dalam tahap pemprosesan ini yakni, reduksi data, penyajian data, dan penarikan kesimpulan. Analisis data deskriptif kualitatif diarahkan pada identifikasi dan klasifikasi untuk mendapat deskripsi yang jelas, rinci dan memadai berkenaan dengan jenis, bentuk dan fungsi tindak tutur berita utama pada koran Bali Post. (1) Reduksi data adalah memilih data yang diperlukan dan menyisihkan data yang tidak diperlukan. Reduksi data dilakukan mulai dari pengumpulan data di lapangan hingga analisis setelah data terkumpul. Di dalam hal ini, penulis mereduksi data menggunakan kartu data untuk memilah jenis, bentuk dan fungsi tindak tutur yang digunakan pada berita utama Koran Bali Post. (2) Setelah data direduksi, maka langkah selanjutnya adalah menyajikan data. Data-data yang diperoleh disajikan uraian data yang berupa kesimpulan informasi yang akan digambarkan secara rinci, jelas, dan sistematis, sehingga memungkinkan penarikan suatu tindakan. Pada tahap ini, data mengenai jenis, bentuk, dan fungsi tindak tutur pada berita utama Koran Bali Post yang dikumpulkan akan dipaparkan dengan jenis wacana deskripsi yang sesuai dengan rancangan penelitian. Pemaparan data akan disesuaikan dengan metode pengumpulan data, yaitu metode dokumentasi. (3) Setelah data dianalisis, maka ditarik kesimpulan berdasarkan masalah yang dikemukakan. Pada tahap penyimpulan ini ditarik simpulan yang sesuai dengan data yang diperoleh dan telah melalui proses analisis data yang meliputi reduksi data dan penyajian data. Jika simpulan yang dikemukakan pada tahap awal didukung oleh bukti-bukti yang valid dan konsisten berdasarkan temuan dilapangan, maka pembuatan simpulannya adalah jawaban dari permasalahan yang sesuai dengan keadaan dan apa adanya. Hasil penelitian ini secermat mungkin menggambarkan tentang apa yang dikaji.

\section{HASIL DAN PEMBAHASAN \\ Hasil Penelitian}

Hasil penelitian ini meliputi (1) Dari 27 berita utama yang peneliti kaji, peneliti memperoleh jenis tindak tutur lokusi sebanyak 27, jenis ilokusi sebanyak 27, dan tidak satupun ditemukan jenis perlokusi. Setiap tuturan akan mengandung lokusi termasuk tuturan yang terdapat pada berita utama. 
Selain lokusi dalam berita utama juga terdapat ilokusi yang berfungsi untuk menginformasikan sesuatu dan dapat juga dipergunakan untuk memengaruhi lawan tutur. Pada berita utama yang peneliti kumpulkan, ke-27 berita utama tiak mengandung perlokusi karena dalam berita utama kita tidak dapat melihat komentar ataupun reaksi para pembaca atau mitra tutur. Dikatakan demikian, karena komentar merupakan efek atau dampak yang timbul dari pembaca, setelah membaca berita utama, dari ke-27 berita utama ternyata tidak ada yang mengandung jenis perlokusi. (2) Untuk bentuk deklaratif yang peneliti temukan berjumlah 27, bentuk interogatif yang peneliti temukan berjumlah 0 , bentuk imperatif yang peneliti temukan berjumlah 0. (3) Untuk fungsi asertif yang peneliti temukan berjumlah 27 , untuk fungsi komisif tidak peneliti temukan atau berjumlah 0 , untuk fungsi direktif yang peneliti temukan berjumlah 4, untuk fungsi ekspresif yang peneliti temukan berjumlah 1 , dan untuk fungsi terakhir yaitu deklaratif berjumlah 1 .

\section{Pembahasan}

Koran merupakan salah satu media massa cetak. Isi utama dalam media massa cetak ini adalah berita. Koran menyajikan berbagai macam informasi dari segala aspek bidang kehidupan. Suatu koran tidak hanya memuat berita-berita politik atau berita-berita ekonomi saja. Akan tetapi ada koran yang memuat tema olahraga, hal tersebut tergantung dari visi, misi, dan tujuan koran masingmasing. Salah satu koran yang terkenal dan beredar di Provinsi Bali adalah koran Bali Post yang juga merupakan koran tertua di Provinsi Bali. Koran Bali Post terdiri atas beberapa rubrik, salah satunya berita utama. Berita utama merupakan berita yang berjenis straight news atau berita langsung. Biasanya dalam berita utama ini disajikan berita yang terbaru atau aktual, apa adanya, serta ditulis secara singkat dan lugas. Ada tiga temuan menarik yang dibahas pada pembahasan ini, yaitu (1) jenis tindak tutur berita utama pada koran Bali Post; (2) bentuk tindak tutur berita utama pada koran Bali Post; (3) fungsi tindak tutur berita utama pada koran Bali Post.

Dari 27 berita utama yang peneliti kumpulkan, ke-27 berita utama tersebut mengandung jenis lokusi dan ilokusi, namun tidak ada satupun berita utama mengandung perlokusi karena dalam berita utama kita tidak dapat melihat komentar ataupun reaksi para pembaca atau mitra tutur. Dikatakan demikian, karena komentar merupakan efek atau dampak yang timbul dari pembaca. Sejalan dengan pendapat Austin (dalam Cummings 2007:9) terdapat pengklasifikasian rangkap tiga terhadap tindak-tindak dalam bertutur, seseorang melakukan tindak lokusi, tindak ilokusi, dan mungkin tindak perlokusi.

Bentuk pada tuturan berdasarkan hasil kajian peneliti, diperoleh bentuk yang dominan, yaitu dari 27 berita utama tersebut bentuk yang dominan adalah bentuk deklaratif sebanyak 27. Bentuk deklaratif ini dominan digunakan karena ke 27 berita utama ini dibuat untuk menyampaikan atau memberikan berita, kabar dan informasi kepada mitra tutur terkait fenomena yang ingin disampaikan atau diangkat untuk dijadikan tuturan pada berita utama. Bentuk interogatif dan bentuk imperatif sangat tidak ditemukan dalam berita utama yang peneliti analisis karena kedua bentuk yang digunakan untuk bertanya dan perintah ini memang sangat jarang digunakan dalam mengungkapkan fenomena-fenomena yang terjadi dalam masyarakat saat ini khususnya ditulis pada berita utama. Hasil penelitian yang diperoleh memiliki 
kemiripan dengan hasil penelitian yang dilakukan oleh Ananda dengan judul penelitian "Bentuk dan Fungsi Tindak Tutur Slogan Varian Iklan Pond's di Televisi" pada tahun 2015 yang menyatakan dari 20 iklan yang Ananda kaji ditemukan 18 slogan yang berbentuk tindak tutur deklaratif karena pada iklan pond's tuturan tersebut dibuat untuk memberikan informasi kepada penonton agar penonton tertarik untuk membeli. Pendapat serupa juga dilontarkan oleh Chaer dan Agustina (2010:50), yang menyatakan bahwa penutur mempertimbangkan norma sosial dan etika tutur dalam menyampaikan setiap tuturan, maka tidak pantas jika menggunakan kalimat imperatif, melainkan kalimat deklaratif atau kalimat interogatif.

Dari segi fungsi tindak tutur, peneliti menemukan berbagai variasi dalam fungsi tindak tutur. Fungsi terbanyak sejumlah 27 yakni fungsi asertif, terbanyak kedua sejumlah 4 merupakan fungsi direktif, terbanyak ketiga jumlahnya masing-masing 1 yaitu fungsi ekspresif dan fungsi deklarasi, dan terakhir fungsi komisif tidak ditemukan. Fungsi asertif lebih dominan karena dalam berita utama fungsi tersebut mengacu pada proposisi menduga, menegaskan kepada pembaca, dan mengumumkan sesuatu kepada pembaca. Fungsi komisif tidak peneliti temukan karena dalam pengertiannya fungsi tersebut mengacu pada menawarkan, berjanji, dan bersumpah, sehingga dari 27 berita utama tidak ditemukan proposisi komisif tersebut karena berita utama tidak digunakan untuk acuan komisif. Sejalan dengan pandangan Searle (dalam Chaer dan Agustina, 2010:19) bahwa berdasarkan fungsinya asertif atau refresentatif adalah tindak tutur yang menjelaskan apa dan bagaimana sesuatu itu ada, dan sebagainya. Verba ini mengacu pada suatu proposisi menguatkan, menduga, menegaskan, meramalkan, memprediksi, mengumumkan, dan mendesak.

Temuan yang penulis dapatkan sesuai dengan temuan yang didapatkan oleh Ratih (2016) dalam skripsinya yang berjudul "Jenis, Bentuk, dan Fungsi Tindak Tutur Meme Comic pada Facebook". Dalam skripsinya, Ratih menyimpulkan bahwa fungsi yang lebih dominan dalam meme comik pada facebook adalah fungsi asertif yaitu tindak tutur yang menjelaskan apa dan bagaimana sesuatu itu ada, dan sebagainya.

Selain peneliti menemukan penelitian yang temuannya sesuai dengan hasil yang peneliti dapat, ada juga peneliti lain yang temuannya tidak sesuai dengan temuan yang peneliti dapat. Temuan yang didapatkan oleh Ananda (2015) dalam skripsinya yang berjudul "Bentuk dan Fungsi Tindak Tutur Slogan Varian Iklan Pond's di Televisi", menyimpulkan bahwa fungsi yang lebih dominan dalam iklan pond's di televisi adalah fungsi komisif, yaitu tindak tutur yang mendorong penutur melakukan sesuatu seperti menawarkan sesuatu kepada mitra tutur. Menurut analisis peneliti, perbedaan itu terjadi karena Ananda mengkaji iklan pond's di televisi, yang berarti iklan itu dibuat untuk membujuk atau mendorong penonton agar membeli produk mereka. Tanpa menganalisis lebih dalam mengenai fungsi tuturan dalam iklan pond's tersebut tidak cukup hanya melihat kalimat melalui penampakannya saja, menurut peneliti suatu iklan juga bisa mengandung tuturan asertif mengumumkan tentang bahan-bahan yang terkandung dan cara menggunakan produk tersebut. Wijana (1996) dalam bukunya yang berjudul "Dasar-dasar Pragmatik" menyatakan bahwa fungsi tindak tutur tampak pada maksud atau tujuan (untuk apa tuturan itu disampaikan). 
Jadi, menganalisis fungsi tindak tutur tidak cukup hanya melihat kalimat melalui penampakannya saja, tetapi juga harus mengetahui maksud kalimat itu karena fungsi tindak tutur dipengaruhi oleh konteks terjadinya tuturan tersebut.

\section{SIMPULAN DAN SARAN}

Berdasarkan pembahasan yang dilakukan pada bab sebelumnya, maka dapat ditarik simpulan sebagai berikut. (1) Dari 27 berita utama yang telah dikaji, diperoleh hasil bahwa ke27 berita utama tersebut mengandung dua jenis tindak tutur yang meliputi tindak tutur lokusi yang digunakan penutur untuk menyatakan sesuatu dan tindak tutur ilokusi yang digunakan untuk memengaruhi, namun tidak ditemukan tindak tutur perlokusi yaitu dampak atau efek yang timbul dari suatu tuturan berupa tanggapan dari pembaca. (2) Dari 27 berita utama yang peneliti teliti, bentuk tindak tutur yang dominan digunakan dalam tuturan berita utama adalah bentuk deklaratif sebanyak 27 bentuk untuk memberikan berita, kabar, dan informasi, bentuk interogatif yang digunakan untuk bertanya, dan imperatif yang digunakan untuk memerintah tidak ditemukan dalam berita utama yang diteliti. (3) Fungsi tindak tutur yang lebih dominan digunakan dalam tuturan berita utama adalah fungsi asertif sebanyak 27 , terbanyak kedua sejumlah 4 merupakan fungsi direktif, terbanyak ketiga dengan jumlah masing-masing 1 yaitu fungsi ekspresif dan fungsi deklarasi, dan terakhir fungsi komisif tidak ditemukan. Fungsi asertif lebih dominan karena dalam berita utama fungsi tersebut mengacu pada proposisi menduga, menegaskan kepada pembaca, dan mengumumkan sesuatu kepada pembaca. Fungsi komisif tidak peneliti temukan karena dalam pengertiannya fungsi tersebut mengacu pada menawarkan, berjanji, dan bersumpah, sehingga dari 27 berita utama tidak ditemukan proposisi komisif tersebut karena berita utama tidak digunakan untuk acuan komisif.

Berdasarkan hasil analisis data dan simpulan di atas, ada beberapa saran yang peneliti sampaikan sebagai berikut. (1) Bagi penulis berita utama agar tetap memperhatikan gaya bahasa yang dipakai dan menggunakan bahasa Indonesia yang baik namun masih memiliki makna yang implisit di dalamnya agar pembaca mudah mengerti apa yang hendak penulis sampaikan. (2) Bagi dosen pengampu mata kuliah pragmatik hasil penelitian ini dapat digunakan sebagai salah satu bahan pembelajaran materi tindak tutur yang mampu meningkatkan kemampuan berpikir kritis mahaiswa. (3) Bagi peneliti lain, penelitian ini baru sebatas pengkajian jenis, bentuk dan fungsi tindak tutur, peneliti lain diharapkan melakukan pengkajian terhadap dampak psikologis yang bisa dilihat dari tuturan berita utama.

\section{DAFTAR PUSTAKA}

Ananda, N.A., Sutama, I.M., Nurjaya, I.G., 2015. Bentuk dan Fungsi Tindak Tutur Slogan Varian Iklan Pond's di Televisi Swasta. J. Jur. Pendidik. Bhs. Dan Sastra Indonesia. 3.

Brodie, R., 2009. Virus of the Mind: The New Science of the Meme. Read HowYouWant.com.

Cahyono, B.Y., 1995. Kristal-Kristal IImu Bahasa. Airlangga University Press, Surabaya.

Chaer, A., Agustina, L., 2010. Sosiolinguistik: Perkenalan Awal Revisi. ed. Rineka Cipta.

Cummings, L., 2007. Pragmatik: Sebuah Perspektif Multidisipliner. Pustaka Pelajar, Yogyakarta.

Dawkins, R., 2016. The Selfish Gene. Oxford University Press. 
Guterres, E.A., 2013. Tindak Tutur Dalam Diskusi Kelas Mahasiswa Semester IV Jurusan Pendidikan Bahasa Dan Sastra Indonesia. Skripsi (tidak diterbitkan). Universitas Pendidikan Ganesha, Singaraja.

Halliday, M.A.K., Ramlan, M., Hasan, R., Tou, A.B., 1992. Bahasa, Konteks, dan Teks: Aspek-Aspek Bahasa dalam Pandangan Semiotik Sosial. Gadjah Mada University Press, Yogyakarta.

Haryanto, P.R.R., 2014. Representasi Kritik Dalam Meme Politik (Studi Semiotika Meme Politik dalam Masa Pemilu 2014 pada Jejaring Sosial "Path" sebagai Media Kritik di Era Siber). Tesis (tidak diterbitkan). Universitas Sebelas Maret, Surakarta.

Kariko, A.A.T., 2012. Humorous Writing Exercise Using Internet Memes On English Classes. Lingua Cult. 6.
Maharani, 2009. Tindak Tutur Percakapan pada Komik Asterix. Skripsi (tidak diterbitkan). Universitas Sumatera Utara

Ratminingsih, M., 2013. Tindak Tutur Guru dalam Proses Belajar Mengajar di TK Wangun Sesana Penarukan Singaraja. Skripsi (tidak diterbitkan). Universitas Pendidikan Ganesha, Singaraja.

Suandi, I.N., 2008. Buku Ajar: Penelitian Bahasa dan Sastra Indonesia. Universitas Pendidikan Ganesha, Singaraja

Sudiara, I.N.S., 1999. Implikatur Percakapan Novel-Novel Anak Agung Pandji Tisna. Tesis (tidak diterbitkan). IKIP Malang, Malang.

Susanti, L.J., 2014. Kesantunan Berbahasa Melalui Pragmatik Tuturan Imperatif. Skripsi (tidak diterbitkan). Universitas Pendidikan Ganesha, Singaraja.

Wijana, D.P., 1996. Dasar-Dasar Pragmatik. ANDI, Yogyakarta. 